behind the US, Canada, Israel and New Zealand.

In terms of sheer numbers, India claims to possess the world's third largest scientific and technical manpower, only behind the US and USSR. India had at the end of 1977, 2.3 million people with qualifications in science, engineering, medicine and agriculture. In April 1976, 54,000 professional scientists were engaged in R\&D work supported by some 40,000 technicians and another 50,000 people engaged in administrative and nontechnical jobs.

China too has a vast stock of scientific and technical manpower. Aqueil Ahmed of the Administrative Staff College of India believes that India and China should be alternatively either third or fourth in international comparisons of scientific manpower. The eight-year science and technology plan (1978-85) recently announced by the Chinese government aims to increase the number of professional $R \& D$ scientists to 800,000 (compared to the total Third World complement of 288,000 in 1973).

But the fact that developing countries spend so little $(2.9 \%)$ on R\&D even though they have a much larger proportion of scientists $(12.6 \%)$, means that each R\&D worker in the developing countries gets few resources to work with. Many scientists have, in fact, emigrated from the Third World to the developed countries complaining that they do not enjoy adequate support.

\section{Military research the big spender}

MORE than a third of the global research and development budget is spent on military and space research, and less than a tenth on health and agricultural research, according to a report published this week by the Worldwatch Institute in Washington. In addition, over $95 \%$ of $R \& D$ funds are spent in the industrialised countries; yet these contain less than $20 \%$ of the global population.

The report, written by Colin Norman, a senior research fellow at the institute, covers ground similar to the Annerstedt report (see left). Norman says that imbalance in research priorities - both between subject areas, and in meeting the needs of the rich rather than the poor urgently need to be reordered. It points out, for example, that the US Government is expected to spend about $\$ 670$ million in 1979 on research and development aimed at improving the productivity of American agriculture; and that this sum far exceeds the agricultural $R \& D$ expenditures of all the developing countries put together.

"The worldwide distribution of R\&D" capacity closely matches the global distribution of economic power," says the report. The disparity applied both to financial and manpower resources. It had been calculated, for example, that during the early 1970s developing countries had about 300 scientists working on R\&D for every million workers, compared to the developed countries, which had 4,000 scientists for every million workers.

The report says that the world's research and development priorities need to be reordered by, for example, channelling more money into neglected research areas, new research organisation and Third World laboratories, as well as encouraging the increasing expenditure by industrialised countries on research appropriate to developing country needs, and stimulating co-operative research efforts between the developing countries themselves.

However, the report warns that such efforts will not, by themselves, be sufficient to solve the world's major problems. "Many tasks are too urgent to wait for R\&D to provide solutions and many cannot be solved by science and technology alone. Indeed when new knowledge is used to bolster and extend the power of governments, corporations and ruling elites, it can aggravate the social injustices that lie at the root of many of the world's most urgent problems," says the report.

Knowledge and Power: The Global Research and Development Budget, by Colin Norman. Worldwatch Paper 31. Available from the Worldwatch Institute, 1776 Massachusetts Avenue NW, Washington DC 20036.

\title{
New US group calls for gene resource conservation programme
}

A DIVERSE group of scientists, concerned over the lack of support for efforts to protect genetic resources met recently in Berkeley, California, to form the National Gene Resource Program Co-ordinating Committee. The committee will initiate a train of events which, it hopes, will culminate in a national conference on gene resource conservation in 1981 .

The committee's first action was to circulate a letter requesting other scientists and people concerned with bioresources to bring the problem to the attention of the federal government.

In an interview with Nature, the coordinator of the committee, geneticist David Kafton, elaborated on the goals of the group. "What we envision is making gene resources a high-priority national issue," he says. The task of the new committee will be to "provide a vehicle for effective action - not iust talk."

Critics of the so-called Green Revolution have long pointed out the double-edged danger of over-reliance on just a few strains of essential crops: the chance that disease could wipe out whole harvests very suddenly and that further breeding potential could be lost forever as wild strains disappear. The devastation left by flare-ups of wheat rust, southern corn leaf blight and Dutch elm disease in the United
States in recent years has illustrated this point.

Some action has been taken. The National Seed Storage Laboratory in Fort Collins, Colorado, has pioneered practical genetic preservation by storing and protecting seeds of more than 100,000 kinds of food and fibre plants. Bernard Finkle, one of the founding members of the new committee, and his colleagues at the Western Regional Research Laboratory of the US Department of Agriculture in Albany, California, have been experimenting with methods of storing in liquid nitrogen the individual cells of plants usually propagated by cuttings rather than seeds.

Such efforts, however, are too poorly funded to assure the preservation of genetic variability for even essential crops, Kafton says. He cites a memorandum sent last March to Secretary of Agriculture, Robert Bergland, by the National Plant Genetic Resources Board - an advisory body to USDA - outlining the need for greater effort in gene conservation. The National Academy of Sciences has also warned that the "genetic diversity for many species is severely threatened" and has recommended the setting up of a new agency for preserving germ plasms.

Meanwhile, an estimated 200 plant species disappear every year, particularly in areas of developing countries where land is cleared to raise fast-growing new hybrids only. Current levels of sample collection preserve only a small fraction of the existing natural diversity of crops and forests, Kafton and his colleagues insist, and too little research is directed towards finding new methods of conservation.

The letter they are now circulating really a petition for action - calls for "the establishment of an effective and comprehensive conservation program to ensure the protection of this nation's irreplaceable and invaluable gene resources." Specifically they call for a national conference "whose primary task will be to initiate and design such a comprehensive program."

Technical support for the committee, and other action groups like it, is being supplied by a small, new, non-profit firm called Inquiring Systems Inc., of Berkeley. Loren Cole, an ecosystemologist, is executive director of the company, and David Kafton is one of the staff scientists. Kafton says that the new company is designed to work with groups like the new gene resource committee to stimulate action on social issues through such activities as organizing meetings, training personnel and publishing information.

John Douglas 